\title{
The Comparative and Usefulness of Platelet Distribution Width in Acute Coronary Syndrome
}

\author{
Idar Mappangara, Ali Aspar Mappahya, Sheila Witjaksono* \\ Department of Cardiology and Vascular Medicine, Faculty of Medicine, Hasanuddin University, Jl. Perintis Kemerdekaan Km.10, Makassar, Indonesia \\ *Corresponding author. E-mail: sheilawitjaksono@yahoo.com
}

Received date: Jul 17, 2016; Revised date: Aug 26, 2016; Accepted date: Sep 21, 2016

\section{Abstract}

$\mathrm{B}$ ACKGROUND: Identifying risk factors for acute coronary syndrome (ACS) is important for both diagnostic and prognostic purposes. Abnormal platelet parameters, mainly platelet count (PC), mean platelet volume (MPV) and platelet distribution width (PDW) are thought to be among these risk factors because platelet activation plays a pivotal role in ACS. PDW is a more specific marker of platelet activation, since it does not increase during simple platelet swelling. In this study, the comparison of risk factors along with the PDW between Non ST-Elevation ACS (NSTEACS) and ST-Elevation ACS (STEACS) were investigated.

METHODS: This is a cross-sectional study, patients with ACS that admitted at dr.Wahidin Sudirohusodo General Hospital Makassar since December 2014 to March 2015 who undergo coronary angiography were enrolled. All data variables were taken according to the medical record. PDW was taken on first blood examination at hospital admission. Data was significant if $p$-value $<0.05$ and was processed with SPSS version 16.

RESULTS: A total of 63 patients were enrolled. There were significantly higher PDW $(p=0.047)$ in STEACS group $(13.7 \pm 2.0 \mathrm{fL})$ than in NSTEACS group $(12.6 \pm 2.3 \mathrm{fL})$. There were a significant positive correlation between PDW value and SYNTAX scores (Pearson, $\mathrm{r}=0.552, p=0.000$ ). Cardiovascular risk factors such as history of ACS before $(p=0.049 \& \mathrm{OR}=10.216)$ and dyslipidemia $(p=0.049 \&$ $\mathrm{OR}=3.915)$ along with $\mathrm{PDW}(p=0.003 \& \mathrm{OR}=1.733)$ were significant predictor of the incidence of multivessel disease in patient with ACS.

CONCLUSION: An increased PDW may predicting more severe disease in ACS based on incidence of STEACS and multivessel disease more often and higher SYNTAX score.

KEYWORDS: platelet distribution width, PDW, acute coronary syndrome, ACS, multivessel disease, SYNTAX

Indones Biomed J. 2016; 8(3): 173-8

\section{Introduction}

Cardiovascular diseases (CVD) account for approximately 12 million deaths annually and are the commonest cause of death globally.(1) Ischaemic heart disease (IHD) is one of CVD that defined as myocardial impairment due to imbalance between coronary blood flow (supply) and myocardial requirement (demand). It is divided into stable angina secondary to coronary artery disease (CAD) and acute coronary syndromes (ACS). ASC is composed of patients with acute myocardial infarction with ST-segment elevation on their presenting electrocardiogram, STElevation ACS (STEACS), and those with unstable angina and non ST-segment elevation myocardial infarction, or non ST-Elevation ACS (NSTEACS).(2) Conventional risk factors for atherosclerosis include smoking, diabetes mellitus, hypertension, dyslipidemia, obesity and stress which either acting singly or in combination increase the chances of developing coronary atherosclerosis. However, 
they only explain part of the cases and other relevant risk factors need to be identified for an accurate calculation of an individual's risk for myocardial infarction.

Platelet indices such as platelet count (PC), mean platelet volume (MPV), and platelet distribution width (PDW) have been well utilized for certain conditions like idiopathic thrombocytopenic purpura (ITP), aplastic anemia and other haemotological and myeloproliferative disorders to assess the prognosis but are underutilized for cardiovascular disorders.(3) Platelets played a role in the pathogenesis of cardiovascular disorders including atherosclerosis and its complications such as ACS and sudden cardiac death. In ACS there was hyperactivity and activation of platelet. Platelet activity is reflected by platelet size which is indirectly measured by the some parameters. Larger platelets are metabolically and enzymatically more active than small platelets.(4) Platelet indices correlate with functional status of platelets and is an emerging risk marker for atherothrombosis.(5) Platelets with increased number and size of pseudopodia differ in size, possibly affecting PDW. PDW is a more specific marker of platelet activation, since it does not increase during simple platelet swelling.(6)

The most sensitive and specific biomarkers of myocardial damage are troponin I and troponin $\mathrm{T}$, levels of both begin to rise at 2 to 4 hours and peak at 48 hours. Creatine Kinase enzymes begins to rise within 2 to 4 hours of the onset of myocardial infarction, peaks at about 24 hours and returns to normal within approximately 72 hours.(7) Platelet parameters can be detected earlier than markers of myocardial infarction. Platelet indices are easily recorded by automated cell counter and are routinely available in most clinical laboratories. There is an aim to make better use of the platelet parameters generated, as patients with larger platelets can easily be identified during routine haematologial analysis and could possibly benefit from timely treatment.(4) The study was undertaken to compare the PDW in STEACS and NSTEACS.

\section{Methods}

This is a cross-sectional study, which took place at Cardiology and Vascular Department, Faculty of Medicine, Hasanuddin University/dr.Wahidin Sudirohusodo General Hospital Makassar. All data variables based on medical record of patients with ACS who admitted at dr.Wahidin Sudirohusodo General Hospital Makassar since December 2014 to March 2015. The inclusion criteria were patients more than 18 years who undergo coronary angiography.
The exclusion criteria were patient with hematology disease and bleeding diathesis, patient with end stage renal disease, patient with carcinoma, patient with active or chronic inflammation, patient with autoimmune disease, patient with active infection, patient with blood transfusion, patient with cardiomyopathy and patient who didn't undergo cardiac catheterization in any cause. Data of blood examination was taken on first blood examination at emergency department when admitted to the hospital.

PDW was taken on first blood examination at hospital admission. Patients were divided into two groups: patients with STEACS and with NSTEACS. Results were expressed as mean \pm standard deviation. Independent $T$ tests were used to compare numerical variables. Chi square tests were used to compare categorical variables. Presence of multivessel disease and SYNTAX score based on coronary angiography. Correlation between continuous variables and SYNTAX score were determined by Pearson's correlation test. Predictor of multivessel disease were determined by logistic regression test. Data was significant if the $p$-value $<0.05$ and processed with SPSS version 16 .

\section{Results}

A total of 63 cases were studied and were divided further into two groups, patients with STEACS and with NSTEACS. The mean age of patients was 53.46 \pm 8.62 years old, with range between 35-72 years old. The mean body weight was $66.62 \pm 12.39 \mathrm{~kg}$, with range between $40-96 \mathrm{~kg}$. The mean body height was $163.19 \pm 5.76 \mathrm{~cm}$, with range between 143 $175 \mathrm{~cm}$. The mean body mass index was $24.93 \pm 4.05 \mathrm{~kg} /$ $\mathrm{m}^{2}$, with range between $16-36.6 \mathrm{~kg} / \mathrm{m}^{2}$. The mean waist circumference was $92.04 \pm 11.39 \mathrm{~cm}$, with range of 61-119 $\mathrm{cm}$. The mean systolic blood pressure was $135.71 \pm 32.27$ $\mathrm{mmHg}$, with range of $60-230 \mathrm{mmHg}$. The mean diastolic blood pressure was $80.48 \pm 21.73 \mathrm{mmHg}$, with range of 0-130 mmHg. The mean random blood glucose was $151.87 \pm 78.19 \mathrm{mg} / \mathrm{dL}$, with range of $73-442 \mathrm{mg} / \mathrm{dL}$. The mean leukocyte was $11,970 \pm 4,891 / \mu \mathrm{L}$, with range of $5,000-27,000 / \mu \mathrm{L}$. The mean PC was $272,000 \pm 74,495 / \mu \mathrm{L}$, with range of $95,000-460,000 / \mu \mathrm{L}$. The mean platelecrit was $0.220 \pm 0.06 \%$ with range of $0.08-0.36 \%$. The mean MPV was $7.88 \pm 1.03 \mathrm{fL}$, with range of $6.3-11 \mathrm{fL}$. The mean PDW was $13.25 \pm 2.18 \mathrm{fL}$, with range of 7.8-17.5 fL. The mean total cholesterol was $193.40 \pm 47.54 \mathrm{mg} / \mathrm{dL}$, with range of $108-328 \mathrm{mg} / \mathrm{dL}$. The mean high density lipoprotein (HDL) cholesterol was $11.20 \pm 33.54 \mathrm{mg} / \mathrm{dL}$, with a range of 9-62 $\mathrm{mg} / \mathrm{dL}$. The mean low density lipoprotein (LDL) cholesterol 
was $129.97 \pm 45.28 \mathrm{mg} / \mathrm{dL}$, with range of $62-247 \mathrm{mg} / \mathrm{dL}$. The mean triglyceride was $168.73 \pm 97.49 \mathrm{mg} / \mathrm{dL}$, with range of 61-643 mg/dL. The mean length of stay was $7.9 \pm 4.67$ days, with range of 1-27 days.

Total number of males was $56(88.9 \%)$ and number of females was $7(11.1 \%)$. The number of males in the STEACS group were $35(62.5 \%)$ compared to NSTEACS group 21 (37.5\%). The numbers of females in the STEACS group were $3(42.85 \%)$ compared to NSTEACS group 4 (57.14\%). In our present study, risk factors were evaluated. Significantly, more number of patients who had history of ACS before and older age were present in NSTEACS than STEACS. Other risk factors did not different significantly among both of them. There were no difference in the incidence of multivessel disease, SYNTAX score group and death in hospital between STEACS and NSTEACS. There was significantly more number of patients who had heart failure in NSTEACS than STEACS (Table 1).

There was statistically significant different in mean ages between STEACS group (51.45 years old) and NSTEACS group (56.52 years old) with $p=0.021$. There was statistically significant different in mean leukocyte between STEACS group (14.08 years old) and NSTEACS group ( 8.76 years old) with $p=0.000$. There was statistically significant different in mean PDW between STEACS group (13.69 years old) and NSTEACS group (12.58 years old) with $p=0.047$. There were not statistically significant different in body weight, body height, body mass index, waist circumference, systolic blood pressure, diastolic blood pressure, random blood glucose, trombocyte, platelecrit, MPV, total cholesterol, LDL cholesterol, HDL cholesterol, triglyserides, uric acid, number of vessel with significant lesion, SYNTAX scores, and length of stay in hospital between STEACS group and NSTEACS group (Table 2).

In this study, we also performed Pearson correlation test to see platelet indices correlation with SYNTAX score. The results of the analysis with Pearson correlation between the PDW and SYNTAX scores showed a very significant positive correlation (Pearson, $\mathrm{r}=0552, p=0.000$ ); while the indices of other platelets and SYNTAX score as platelet count (Pearson, $\mathrm{r}=-0159, p=0214$ ), platelecrit (Pearson, $\mathrm{r}=0.065, p=0612$ ) and MPV (Pearson, $\mathrm{r}=0185$, $p=0.147$ ) did not show a significant correlation with SYNTAX score.

We analyse risk factor along with platelet indices and other variables with logistic regression to search factor or parameter that can predict the incidence of multivessel disease. The mean PDW in the group with multivessel disease was $13.9 \pm 1.9 \mathrm{fL}$, while in the group without multivessel
Table 1. Comparison of categorical variables in STEACS and NSTEACS.

\begin{tabular}{|c|c|c|c|c|}
\hline \multirow{2}{*}{ Risk Factor } & \multirow{2}{*}{ Total } & \multicolumn{2}{|c|}{ ACS } & \multirow{2}{*}{$p$} \\
\hline & & STEACS & NSTEACS & \\
\hline \multicolumn{5}{|l|}{$\operatorname{Sex}$} \\
\hline Male & 56 & 35 & 21 & 0.317 \\
\hline Female & 7 & 3 & 4 & \\
\hline \multicolumn{5}{|c|}{ Family History of CAD } \\
\hline No & 51 & 29 & 22 & 0.248 \\
\hline Yes & 12 & 9 & 3 & \\
\hline \multicolumn{5}{|l|}{ History of ACS } \\
\hline No & 48 & 35 & 13 & 0.000 \\
\hline Yes & 15 & 3 & 12 & \\
\hline \multicolumn{5}{|l|}{ Hypertension } \\
\hline No & 26 & 18 & 8 & 0.225 \\
\hline Yes & 37 & 20 & 17 & \\
\hline \multicolumn{5}{|l|}{ Diabetes Mellitus } \\
\hline No & 52 & 31 & 21 & 0.804 \\
\hline Yes & 11 & 7 & 4 & \\
\hline \multicolumn{5}{|l|}{ Dyslipidemia } \\
\hline No & 31 & 19 & 12 & 0.877 \\
\hline Yes & 32 & 19 & 13 & \\
\hline \multicolumn{5}{|l|}{ History of Stroke } \\
\hline No & 63 & 38 & 25 & - \\
\hline Yes & 0 & 0 & 0 & \\
\hline \multicolumn{5}{|l|}{ Smoking } \\
\hline No & 15 & 6 & 9 & 0.065 \\
\hline Yes & 48 & 32 & 16 & \\
\hline \multicolumn{5}{|c|}{ Obesity $\left(\right.$ BMI $\left.>25 \mathrm{~kg} / \mathrm{m}^{2}\right)$} \\
\hline No & 35 & 21 & 14 & 0.954 \\
\hline Yes & 28 & 17 & 11 & \\
\hline \multicolumn{5}{|l|}{ Central Obesity } \\
\hline No & 28 & 19 & 9 & 0.274 \\
\hline Yes & 35 & 19 & 16 & \\
\hline \multicolumn{5}{|l|}{ Multivessel Disease } \\
\hline No & 22 & 14 & 8 & 0.693 \\
\hline Yes & 41 & 24 & 17 & \\
\hline \multicolumn{5}{|l|}{ SYNTAX score group } \\
\hline Low $(\leq 22)$ & 40 & 26 & 14 & 0.316 \\
\hline Moderate-High $(>22)$ & 23 & 12 & 11 & \\
\hline \multicolumn{5}{|c|}{ Presence of Heart Failure } \\
\hline No & 30 & 14 & 16 & 0.035 \\
\hline Yes & 33 & 24 & 9 & \\
\hline \multicolumn{5}{|l|}{ Death in Hospital } \\
\hline No & 60 & 37 & 23 & 0.328 \\
\hline Yes & 3 & 1 & 2 & \\
\hline
\end{tabular}

disease was $11.9 \pm 1.9 \mathrm{fL}$. Statistical analysis showed that PDW mean significantly different with $p=0.000$. Other platelet indices such as platelet count $(p=0.649)$, platelecrit $(p=0.446)$ and MPV $(p=0.591)$ do not have statistically significant association with multivessel disease. Other risk factors such as history of ACS ( $p=0.009)$, dyslipidemia ( $p=0.027)$ and age $(p=0.024)$ also had significant association with multivessel disease (Table 3 ).

Table 4 shows that history of ACS, dyslipidemia, age and PDW were analyzed by logistic regression. Statistically 
Table 2. Comparison the mean of numerical variables in STEACS and NSTEACS.

\begin{tabular}{|c|c|c|c|c|}
\hline & SKA Group & $\mathbf{n}$ & mean $\pm S D$ & $p$ \\
\hline \multirow{3}{*}{ Age (years) } & NSTEACS & 25 & $56.52 \pm 8.88$ & \multirow{3}{*}{0.021} \\
\hline & STEACS & 38 & $51.45 \pm 7.93$ & \\
\hline & Total & 63 & $53.46 \pm 5.62$ & \\
\hline \multirow{3}{*}{ Body Weight (kg) } & NSTEACS & 25 & $66.36 \pm 13.00$ & \multirow{3}{*}{0.894} \\
\hline & STEACS & 38 & $66.79 \pm 12.14$ & \\
\hline & Total & 63 & $66.62 \pm 12.39$ & \\
\hline \multirow{3}{*}{ Body Height (cm) } & NSTEACS & 25 & $162.48 \pm 4.74$ & \multirow{3}{*}{0.431} \\
\hline & STEACS & 38 & $163.66 \pm 6.36$ & \\
\hline & Total & 63 & $163.19 \pm 5.76$ & \\
\hline \multirow{3}{*}{ BMI $\left(\mathrm{kg} / \mathrm{m}^{2}\right)$} & NSTEACS & 25 & $25.09 \pm 4.56$ & \multirow{3}{*}{0.801} \\
\hline & STEACS & 38 & $24.83 \pm 3.74$ & \\
\hline & Total & 63 & $24.93 \pm 4.05$ & \\
\hline \multirow{3}{*}{ Waist Circumference (cm) } & NSTEACS & 25 & $91.84 \pm 11.52$ & \multirow{3}{*}{0.911} \\
\hline & STEACS & 38 & $92.17 \pm 11.45$ & \\
\hline & Total & 63 & $92.04 \pm 11.39$ & \\
\hline \multirow{3}{*}{ Sistolic Blood Pressure (mmHg) } & NSTEACS & 25 & $141.6 \pm 39.34$ & \multirow{3}{*}{0.243} \\
\hline & STEACS & 38 & $131.84 \pm 26.49$ & \\
\hline & Total & 63 & $135.71 \pm 32.27$ & \\
\hline \multirow{3}{*}{ Diastolic Blood Pressure (mmHg) } & NSTEACS & 25 & $81.2 \pm 25.55$ & \multirow{3}{*}{0.832} \\
\hline & STEACS & 38 & $80 \pm 19.17$ & \\
\hline & Total & 63 & $80.48 \pm 21.73$ & \\
\hline \multirow{3}{*}{ Random Blood Glucose (mg/dL) } & NSTEACS & 25 & $133.92 \pm 45.19$ & \\
\hline & STEACS & 38 & $163.68 \pm 92.52$ & 0.141 \\
\hline & Total & 63 & $151.87 \pm 78.20$ & \\
\hline & NSTEACS & 25 & $8.76 \pm 2.21$ & \\
\hline Leukocyte $\left(10^{3} / \mu \mathrm{L}\right)$ & STEACS & 38 & $14.08 \pm 5.04$ & 0.000 \\
\hline & Total & 63 & $11.97 \pm 4.89$ & \\
\hline & NSTEACS & 25 & $269.48 \pm 65.75$ & \\
\hline Trombocyte $\left(10^{3} / \mu \mathrm{L}\right)$ & STEACS & 38 & $274.5 \pm 80.53$ & 0.796 \\
\hline & Total & 63 & $272.51 \pm 74.50$ & \\
\hline & NSTEACS & 25 & $0.22 \pm 0.59$ & \\
\hline Plateletcrit (\%) & STEACS & 38 & $0.21 \pm 0.06$ & 0.739 \\
\hline & Total & 63 & $0.22 \pm 0.06$ & \\
\hline & NSTEACS & 25 & $8.03 \pm 1.17$ & \\
\hline MPV (fL) & STEACS & 38 & $7.78 \pm 0.93$ & 0.351 \\
\hline & Total & 63 & $7.88 \pm 1.03$ & \\
\hline & NSTEACS & 25 & $12.58 \pm 2.25$ & \\
\hline PDW (fL) & STEACS & 38 & $13.69 \pm 2.05$ & 0.047 \\
\hline & Total & 63 & $13.25 \pm 2.18$ & \\
\hline & NSTEACS & 25 & $200.8 \pm 48.91$ & \\
\hline Total Cholesterol (mg/dL) & STEACS & 38 & $188.53 \pm 46.63$ & 0.320 \\
\hline & Total & 63 & $193.4 \pm 47.54$ & \\
\hline & NSTEACS & 25 & $36.32 \pm 9.49$ & \\
\hline HDL Cholesterol (mg/dL) & STEACS & 38 & $31.71 \pm 11.97$ & 0.111 \\
\hline & Total & 63 & $33.54 \pm 11.20$ & \\
\hline & NSTEACS & 25 & $138.92 \pm 48.80$ & \\
\hline LDL Cholesterol (mg/dL) & STEACS & 38 & $124.08 \pm 42.44$ & 0.206 \\
\hline & Total & 63 & $129.97 \pm 45.28$ & \\
\hline & NSTEACS & 25 & $164.36 \pm 94.32$ & \\
\hline Triglys erides (mg/dL) & STEACS & 38 & $171.61 \pm 100.67$ & 0.776 \\
\hline & Total & 63 & $168.73 \pm 97.49$ & \\
\hline & NSTEACS & 25 & $7.31 \pm 2.20$ & \\
\hline Uric Acid (mg/dL) & STEACS & 38 & $6.57 \pm 2.33$ & 0.212 \\
\hline & Total & 63 & $6.86 \pm 2.29$ & \\
\hline & NSTEACS & 25 & $1.92 \pm 1$ & \\
\hline Number of v esser With signiricant & STEACS & 38 & $1.92 \pm 0.88$ & 0.997 \\
\hline & Total & 63 & $1.92 \pm 0.92$ & \\
\hline & NSTEACS & 25 & $16.26 \pm 10.43$ & \\
\hline SYNTAX Score & STEACS & 38 & $15.67 \pm 10.60$ & 0.829 \\
\hline & Total & 63 & $15.91 \pm 10.45$ & \\
\hline & NSTEACS & 25 & $7.44 \pm 3.32$ & \\
\hline Length of Stay in Hospital (days) & STEACS & 38 & $8.21 \pm 5.4$ & 0.526 \\
\hline & Total & 63 & $7.9 \pm 4.67$ & \\
\hline
\end{tabular}

*Data was significant if the $p$-value $<0.05$ 
Table 3. Comparison between multivessel disease group.

\begin{tabular}{|c|c|c|c|}
\hline \multirow{2}{*}{ Risk Factor } & \multicolumn{2}{|c|}{ Multivessel Disease } & \multirow{2}{*}{$p$} \\
\hline & Yes $(n=41)$ & No $(n=22)$ & \\
\hline \multicolumn{4}{|l|}{$\operatorname{Sex}$} \\
\hline Male & 36 & 20 & 0.709 \\
\hline Female & 5 & 2 & \\
\hline \multicolumn{4}{|l|}{ Family History of CAD } \\
\hline Yes & 8 & 4 & 0.898 \\
\hline No & 33 & 18 & \\
\hline \multicolumn{4}{|l|}{ History of ACS } \\
\hline Yes & 14 & 1 & 0.009 \\
\hline No & 27 & 21 & \\
\hline \multicolumn{4}{|l|}{ Hypertension } \\
\hline Yes & 25 & 12 & 0.621 \\
\hline No & 16 & 10 & \\
\hline \multicolumn{4}{|l|}{ Diabetes Mellitus } \\
\hline Yes & 9 & 2 & 0.200 \\
\hline No & 32 & 20 & \\
\hline \multicolumn{4}{|l|}{ Dyslipidemia } \\
\hline Yes & 25 & 7 & 0.027 \\
\hline No & 16 & 15 & \\
\hline \multicolumn{4}{|l|}{ History of Stroke } \\
\hline Yes & 0 & 0 & - \\
\hline No & 41 & 22 & \\
\hline \multicolumn{4}{|l|}{ Smoking } \\
\hline Yes & 31 & 17 & 0.883 \\
\hline No & 10 & 5 & \\
\hline \multicolumn{4}{|l|}{ Obesity $\left(\right.$ BMI $\left.>25 \mathrm{~kg} / \mathrm{m}^{2}\right)$} \\
\hline Yes & 17 & 11 & 0.516 \\
\hline No & 24 & 11 & \\
\hline \multicolumn{4}{|l|}{ Central Obesity } \\
\hline Yes & 24 & 11 & 0.516 \\
\hline No & 17 & 11 & \\
\hline \multicolumn{4}{|l|}{ Presence of Heart Failure } \\
\hline Yes & 23 & 10 & 0.420 \\
\hline No & 18 & 12 & \\
\hline \multicolumn{4}{|l|}{ Death in hospital } \\
\hline Yes & 3 & 0 & 0.194 \\
\hline No & 38 & 22 & \\
\hline Age (years) & $55.2 \pm 8.7$ & $50.1 \pm 7.6$ & 0.024 \\
\hline Body Weight (kg) & $65.9 \pm 13.5$ & $67.8 \pm 10.1$ & 0.563 \\
\hline Body Height (cm) & $162.9 \pm 6.4$ & $163.6 \pm 4.5$ & 0.689 \\
\hline BMI $\left(\mathrm{kg} / \mathrm{m}^{2}\right)$ & $24.7 \pm 4.3$ & $25.3 \pm 3.5$ & 0.561 \\
\hline Waist Circumferences (cm) & $92.1 \pm 12.4$ & $91.8 \pm 9.5$ & 0.920 \\
\hline Sistolic Blood Pressure (mmHg) & $134.2 \pm 29.1$ & $138.6 \pm 38.1$ & 0.603 \\
\hline Diastolic Blood Pressure (mmHg) & $80.0 \pm 20.6$ & $81.4 \pm 24.1$ & 0.815 \\
\hline Random Blood Glucose (mg/dL) & $153.6 \pm 77.7$ & $148.6 \pm 80.9$ & 0.812 \\
\hline Leukocyte $\left(10^{3} / \mu \mathrm{L}\right)$ & $11.2 \pm 4.4$ & $13.3 \pm 6.1$ & 0.104 \\
\hline $\mathrm{PC}\left(10^{3} / \mu \mathrm{L}\right)$ & $269.3 \pm 74.8$ & $278.4 \pm 75.3$ & 0.649 \\
\hline Plateletcrit (\%) & $0.219 \pm 0.06$ & $0.278 \pm 0.06$ & 0.446 \\
\hline MPV (fL) & $7.9 \pm 0.8$ & $7.8 \pm 1.4$ & 0.591 \\
\hline PDW (fL) & $13.9 \pm 1.9$ & $11.9 \pm 1.9$ & 0.000 \\
\hline Total Cholestrol (mg/dL) & $197.3 \pm 52.3$ & $186.1 \pm 37.0$ & 0.376 \\
\hline HDL Cholestrol (mg/dL) & $32.7 \pm 12.5$ & $35.1 \pm 8.3$ & 0.412 \\
\hline LDL Cholestrol (mg/dL) & $137.5 \pm 51.6$ & $116 \pm 25.7$ & 0.073 \\
\hline Trygliserides (mg/dL) & $161.1 \pm 104.6$ & $182.9 \pm 83.1$ & 0.402 \\
\hline Uric Acid (mg/dL) & $7.2 \pm 2.6$ & $6.2 \pm 1.3$ & 0.082 \\
\hline Length of stay in Hospital (days) & $7.3 \pm 3.5$ & $9.1 \pm 6.3$ & 0.157 \\
\hline
\end{tabular}

analyse showed that age is no longer a predictor of the incidence of multivessel disease with $p=0.352$; whereas history of ACS $(p=0.049 \& \mathrm{OR}=10.216)$, dyslipidemia $(p=0.049 \& \mathrm{OR}=3.915)$ and $\mathrm{PDW}(p=0.003 \& \mathrm{OR}=1.733)$ are a significant predictor of the incidence of multivessel disease.

Table 4. Logistic regression analysis of history SKA, dyslipidemia, age, and PDW with incidence of multivessel disease.

\begin{tabular}{lcccc}
\hline & B & SE & $\boldsymbol{p}$ & OR \\
\hline History of ACS & 2.324 & 1.181 & 0.049 & 10.216 \\
Dyslipidemia & 1.365 & 0.693 & 0.049 & 3.915 \\
Age & 0.041 & 0.044 & 0.352 & 1.042 \\
PDW & 0.550 & 0.186 & 0.003 & 1.733 \\
Constant & -9.643 & 3.223 & 0.003 & 0.000 \\
\hline
\end{tabular}

*Logistic regression analyze was significant if the $p$-value $<0.05$

\section{Discussion}

This study showed that mean PDW value was higher in STEACS than NSTEACS. It has been known that STEACS was more severe than NSTEACS. Pathophysiologically, NSTEACS is somewhat different from STEACS. NSTEACS caused by complete occlusion of a minor coronary artery or a partial occlusion of a major coronary artery and its causes a partial damage of heart muscle. STEACS caused by a complete occlusion of a major coronary artery and its causes a full damage of heart muscle. Both of them can make some complications. But some complications like cardiogenic shock, left ventricular failure (like in this study), severe mitral regurgitation due to papillary muscle rupture, cardiac tamponade due to ventricular wall rupture are more in STEACS (due to full thickness heart muscle damage) than NSTEACS.

There were significantly higher leukocytes in STEACS than NSTEACS. This result is similar with previous study that conclude STEACS patients have significantly higher peak CRP levels compared to NSTEACS patients and suggest that inflammatory processes play an independent role in the pathogenesis of myocardial infarction.(8) There were significantly higher PDW in STEACS than NSTEACS. In ACS, rupture of unstable plaque activated the thrombogenic cascade. However, platelet reactivity plays a vital role in the 
formation and propagation of intracoronary thrombus.(9) Other platelet indices such as platelet count, platelecrit, and MPV did not significantly different between STEACS and NSTEACS. This result similar with study by Vagdatli, et al., which conclude that PDW is a more specific marker of platelet activation.(6)

PDW has a positive correlation with SYNTAX scores. This result is similar with study by Bekler, et al., that conclude PDW is associated with severity of CAD based on Gensini score (10) and study by Akin, et al., that conclude PDW is a cheap and easy laboratory test which independently associated with high SYNTAX score (11). We also divided patients into multivessel disease group and no multivessel group, so we may predict the incidence of multivessel disease because it associated with poor prognosis.(12) Analyzing the data with logistic regression, we found that PDW among with history of ACS before and dyslipidemia are statistically significant to predicting multivessel disease. We all have known that history of ACS before and dyslipidemia are well known cardiovascular risk factors that had been proven influence the incidence of multivessel disease.

Limitations of the study include the small sample size and only done in one place. The study also did not follow up the patient to see that PDW value can be used as a marker of future cardiovascular events.

\section{Conclusion}

Platelet distribution width in STEACS group is higher than in NSTEACS group. The higher PDW, SYNTAX score will also be higher. Platelet distribution width is also higher in multivessel group. In this study, PDW may be useful to predict more severe disease in ACS based on incidence of multivessel disease and SYNTAX score.

\section{References}

1. Shah SN, Anand MP, Billimoria AR, Kamath SA, Karnad DR. API textbook of Medicine. 8th edition. New Delhi: Jaypee Brothers Medical Publishers; 2008.

2. Fauci AS, Kasper DL, Longo DL, Braunwald E, Hauser S. Harrison's Principles of Internal Medicine. 17th edition. New Delhi: Mc Graw Hill Medical; 2008.

3. Kaito K, Otsubo H, Usui N, Yoshida M, Tanno J, Kurihara E, et al. Platelet size deviation width, platelet large cell ratio, and mean platelet volume have sufficient sensitivity and specificity in the diagnosis of immune thrombocytopenia. Br J Haematol. 2005; 128: 698-702.

4. Khandekar MM, Khurana AS, Deshmukh SD, Ka-krani AL, Katdare $\mathrm{AD}$, Inamdar AK. Platelet volume indices in patients with coronary artery disease and acute myocardial infarction. J Clin Pathol. 2006; 59: 146-9.

5. Lippi G, Filippozzi L, Salvagno GL, Montagnana M, Franchini $\mathrm{M}$, Guidi GC, et al. Increased mean platelet volume with acute coronary syndromes. Arch Pathol Lab Med. 2009; 133: 1441-3.

6. Vagdatli E, Gounari E, Lazaridou E, Katsibourlia E, Tsikopoulou F, Labrianou I. Platelet distribution width: a simple, practical and specific marker of activation of coagulation. Hippokratia. 2010; 14 : 28-32.

7. Kumar V, Abbas AK, Fauselto N, Aster JC. Robbins and Cotran Pathologic Basis of Disease. 8th edition. New Delhi: Elsevier; 2010.

8. Habib SS, Kurdi MI, Al Aseri Z, Suriya MO. CRP levels are higher in patients with ST elevation than non-ST elevation acute coronary syndrome. Arq Bras Cardiol. 2011; 96: 13-7.

9. Martin JF, Bath PM, Burr ML. Influence of platelet size on outcome after MI. Lancet. 1991; 338: 1409-11.

10. Bekler A, Ozkan MT, Tenekecioglu E, Gazi E, Yener AU, Temiz A, et $a l$. Increased platelet distribution width is associated with severity of coronary artery disease in patients with acute coronary syndrome. Angiology. 2015; 66: 638-43.

11. Akin F, Ayca B, Kose N, Altun I, Avsar M, Celik O, et al. Relation of platelet indices to severity of coronary artery disease in patients undergoing primary percutaneous coronary intervention. Perfusion. 2016; 31: 216-22.

12. Sorajja P, Gersh BJ, Cox DA, McLaughlin MG, Zimetbaum P, Costantini $\mathrm{C}$, et al. Impact of multivessel disease on reperfusion success and clinical outcomes in patients undergoing primary PCI for AMI. Eur Heart J. 2007; 28: 1709-16. 